\title{
UNIVERSITYOF
}

FORWARD

THINKING

WESTMINSTER用

WestminsterResearch

http://www.westminster.ac.uk/westminsterresearch

Agonism Reloaded: Potentia, Renewal and Radical Democracy

Tambakaki, P.

This is a copy of the accepted author manuscript of the following article: Tambakaki, P. (2016) Agonism Reloaded: Potentia, Renewal and Radical Democracy, Political Studies Review, pp. 1-12. The final definitive version is available from the publisher Sage at:

https://dx.doi.org/10.1177/1478929916635882

(C) The Author(s) 2016

The WestminsterResearch online digital archive at the University of Westminster aims to make the research output of the University available to a wider audience. Copyright and Moral Rights remain with the authors and/or copyright owners.

Whilst further distribution of specific materials from within this archive is forbidden, you may freely distribute the URL of WestminsterResearch: ((http://westminsterresearch.wmin.ac.uk/).

In case of abuse or copyright appearing without permission e-mail repository@westminster.ac.uk 


\section{Agonism Reloaded: Potentia, Renewal and Radical Democracy}

B. Honig (2013) Antigone, Interrupted. Cambridge: Cambridge University Press M. Wenman (2013) Agonistic Democracy: Constituent Power in the Era of Globalisation. Cambridge: Cambridge University Press

R. Nichols and J. Singh (eds) (2014) Freedom and Democracy in an Imperial Context - Dialogues with James Tully. Abingdon and New York: Routledge C. Mouffe (2013) Agonistics. London: Verso.

J. Tully (ed.) (2014) On Global Citizenship. James Tully in Dialogue. London and New York: Bloomsbury Academics.

\section{Introduction}

Discontent with democracy has gone into new heights in the wake of the Euro-crisis, the indignados and the Occupy movements. Read as symptoms of democratic stagnation, such recent events have yielded lively debates on the limits of democracy, propelling reflections on political change to the forefront of theoretico-political analysis. In this context, it comes as little surprise that theories of radical democracy have taken a lead in laying out the contours of another, more democratic, world. Their attention to division, contestability and openness has placed them in the unique position of offering accounts of change that combine robust critiques of the exclusions and antagonisms publicised by the Occupy movements (socio-economic, institutional and representative) with the insistence that an alternative is possible without compromising difference and openness.

To grasp the intricacies of this combination it is important to notice that the account of political change outlined by radical democrats is filtered through the ontological presupposition of a constitutive or 'radical difference' that dissects and subverts orders considered fixed, consensual or universal (Tønder and Thomassen, 2005). This suggests that change is envisaged in terms that are neither too thick (so that it foists closure on politics) nor too thin (so that it simply assents to the status quo). Rather, change is itself configured as a process, sometimes even as a political project, that emerges out of, dwells on, and remains open to ongoing challenges by difference whether this difference is conceived as a constitutive antagonism (in Žižek 2011-, Laclau and Mouffe 2001); the multitude (Hardt and Negri 2012); the inexistent (Badiou 2012) or the part-of-no part (Rancière 1999). Indeed, the different accounts of radical difference indicate not just that we are confronting often sharp divisions 
within trajectories of radical democracy, as Tønder and Thomassen highlight, but also that we are dealing with a rather large pool of radical democrats - even theorists who eschew the term 'radical democracy' (Žižek 2011, pp.392-3), advocate an 'absolute', non-representative, democracy (Hardt and Negri, 2012) or insist on communism instead of democracy (Badiou, 2012).

No doubt, one can retort that the very rejection of democracy and its institutions, coupled with the sharp divisions within the field apropos of the modalities of political change hollow out 'radical democracy' as an umbrella term. This objection is valid if one confines radical democracy to the pluralisation and extension of democratic struggles within the frame of liberal democratic institutions - in other words, to Laclau and Mouffe's work (2001) where the term has found its most eloquent expression. However, if by 'radical democracy' one understands a strand of political theory held together by a set of ontological, often post-structuralist, presuppositions on the irreducibility of difference in accounts of politics and by a pronounced concern with the ways in which popular struggles, many and bottom-up, enframe alternatives that unravel dominant scripts - disrupting and changing these - then both the large pool of theorists and the divisions between them make more sense.

On this account of radical democracy, agonistic theory which the books under review expound to varying degrees, illustrates one distinctive line of thought. Developed over the course of two decades in the work of Chantal Mouffe, Bonnie Honig, William Connolly and James Tully, agonistic theory sets out an account of political change that displays nuanced differences from other vocabularies of radical democracy. Like these vocabularies, agonistic theory stresses the irreducibility of difference in accounts of democracy and the invaluable role that popular struggles play in eliciting socio-political change (particularly social movements). Unlike other vocabularies of radical democracy, however, agonistic theory ties political change with the modality of democratic renewal - rather than transformation (Žižek, 2011; Badiou, 2012; Hardt and Negri, 2012) or reactivation (Wolin, 1996; Rancière, 1999).

The idea of the agon is lodged at the centre of the agonistic account of renewal. Understood as a moderate, respectful and ongoing type of contest, the agon elicits renewal partly because it encourages democratic openness and partly because it 
sustains it. Agonistic contests enable democratic openness by giving expression to constitutive differences suppressed or silenced within pluralistic democracies. They sustain openness by exposing and challenging the closures, normalisations and exclusions produced by institutional democracies. They disturb their fixities and they pluralise - open up, expand and extend - the perspectives, practices, norms and sites of democratic politics. Agonistic contests, thus, renew contemporary democracies in a specific sense: they rework their dominant facets, continuously opening them up. They neither transform (in the sense of overturning) nor reactivate the institutional, representative and liberal dimensions of contemporary democracies.

This explains why the agonistic account of renewal has often been dismissed in relevant discussions in the broader literature. While the idea of pluralisation and its relation with contestation has often been used to distinguish agonistic theory from deliberative democracy and mainstream liberal theory (or meld them together, depending on where one stands); the emphasis on renewal has not as often brought agonistic theory in contact with theories of radical democracy (Mouffe's work aside). In the few instances that the two have been invoked together it has been to foreground either their shared post-structuralist ontology (particularly in the case of Mouffe and Connolly) or, simply, their incompatibility (Wingenbach, 2011).

The books under review suggest that we think twice before we dismiss the agonistic account of renewal and its place within the broader horizon of radical democracy. While the books by Bonnie Honig, James Tully and Chantal Mouffe re-elaborate on ideas first developed in the early 2000s, they also delve deeper into the current context, they reassert these ideas, and evoke contrasts with other accounts of radical democracy (particularly Honig and Mouffe). As a result of the explicit references and sometimes allusions to radical democracy the reader is inclined to reflect on the exchange between agonism and trajectories of radical democracy - a reflection that Mark Wenman's book_, especially his critique of the agonistic account of renewal, strongly invites.

This reflection is taken up in the first and last parts of the review. In particular, the first section outlines the agonistic account of renewal, setting out the commonalities among the agonistic theories of Honig, Tully and Mouffe. At the same time, the first 
section explores some differences between agonistic theorists and other radical democrats, seeking to identify where the radical import of agonistic theory lies. Subsequent sections attend to the specific differences between Honig, Tully and Mouffe and, thus, provide a fuller account of the type of renewal envisaged by the different theorists. Mark Wenman's interesting attempt to reload agonism by aligning its assumptions with the idea of radical initiative is discussed and assessed in the last section.

\section{The Agonistic Account of Democratic Renewal}

The preceding discussion suggested that agonistic theorists, in contrast with other radical democrats, conceive of political change in the modality of democratic renewal. One way to grasp the particularity of the dimension of renewal, as conceived by agonistic theorists, is to contrast it with the two modalities of change advanced by other radical democrats: transformation (Žižek, 2011; Badiou, 2012; Hardt and Negri, 2012) and reactivation (Wolin, 1996; Rancière, 1999). The contrast is analytically useful because it gives a first impression of the range of ideas that the books under review take issue with.

The first idea that emerges to divide agonistic theorists from those radical democrats who advocate a transformative politics is that of a radical rupture, a revolutionary break from institutional politics that will open the way for a new, more egalitarian, society - designated as communism. While all agonistic theorists disagree with the idea of a radical rupture with institutional politics, they give different reasons for their disagreement. For Chantal Mouffe in Agonistics a radical break is not required. There are other ways to address the limits of contemporary democracies and she suggests a Gramscian 'war of position' within institutions (134), for a new society fully liberated from institutions can never arrive. Divisions, power and antagonisms, constitutive of the socio-political field, will not only prevent the arrival of the type of 'reconciled' society that theorists such as Alain Badiou and Michael Hardt and Antonio Negri suggest, but they will also require institutions to tame and turn them into agons (84). In the next section I will explain further why Mouffe's institutional route to change does not come down to another approach to transformative politics - as it might be readily assumed from her continued insistence since 1985 on the need to construct a 
counter-hegemonic politics. Here suffice to notice that while Mouffe's preferred path to renewal keeps open the possibility of democratic change, this falls short of the institutional overturning envisioned by theorists such as Žižek, Badiou and Hardt and Negri.

James Tully agrees with Mouffe that a radical break with institutional democracy is not required, but he is less sanguine_about the role that institutions can play in the deepening of democratic functions. In Global Citizenship he suggests that an alternative way to democratic reform is through everyday struggles that empower those subject to relations of governance and, thus, work to ameliorate, deepen and renew institutional politics. Along similar lines, Bonnie Honig cites everyday, ordinary, struggles as sources of democratic renewal. In Antigone Interrupted, she reinterprets Antigone as an ordinary political actor and shows how ordinary work of repair can have more far-reaching implications for contemporary democracies than aspirations to break from and overturn their institutions. It is noteworthy, then, that all agonistic theorists insist, first, that it is unnecessary to look to the creation of a new society; second, Honig, Tully and Mouffe also suggest that it is possible to renew contemporary democracies by engaging in agons that disrupt and open up, but never undo, existing institutional politics.

Mark Wenman ties this approach to renewal with the Arendtian modality of augmentation. The modality of augmentation, he elaborates in Agonistic Democracy, enframes a particular way of experiencing freedom that 'simultaneously expands and preserves an existing system of authority' (9). Wenman associates the productive dimension of this type of freedom with pronounced features of the agonistic contest. Subjects who contest systemic rules do so in a non-dialectical way and from a prejuridical position that cannot be subsumed into constituted authority. The agon politically subjectifies them and, thus, puts them in a position to genuinely renegotiate and alter constituted rules, practices and institutions. However, this renegotiation is always an augmentation of existing rules and practices, stresses Wenman. It is not the creation of 'a new set of norms and values into the world, as it were ex nihilo' (9). The Arendtian modality of revolution, as distinct from augmentation, transpires as a 
theoretical impossibility for agonistic theorists, because the agon only ever expands the background rules of liberal and institutional democracy.

To grasp further the reasons behind this theoretical impossibility, it is useful to delve into Mouffe's, Tully's and Honig's account of the agon from a slightly different angle to Wenman's. This angle draws attention to the additional feature that the agons are conflicts that are moderate and democratic. They are not expressing a pure antagonism toward the system, let alone an economic or class-based one as theorists such as Badiou (2012) and Žižek (2011) outline. They do away with pure antagonism because they are designed to give expression to the various differences of situated subjects seeking to improve the frame of liberal democracy. It follows that if agonism exemplifies an already limited and democratic expression of difference, it cannot go against the institutions of liberal democracy. To radically question the role of institutions would be to fall back to a type of conflict that cannot be considered as a democratic resource. By contrast, for Badiou and Žižek division and proletarianisation permeate contemporary societies so deeply that it is impossible to envision a more democratic and equal world without first radically challenging ordinary politics - the institutional, liberal, and democratic framework- and, second, offering an alternative vision where division 'acquires the stability of a new form of life' - namely, communism (Žižek, 2011, p. 475).

To offer an alternative vision, however, in the form of, say, egalitarianism is from an agonistic perspective to initiate closure. Egalitarianism is an epiphenomenon of agonism for Tully, Honig and Mouffe (Wenman, 2012, 296). It is not the harbinger of a better politics, a 'de-fetishized democracy' that has done away with the institutional mechanisms that reproduce capitalist relations of domination (Žižek, 2011, 450). For this reason, the agonistic account of renewal has been criticised for staying too close to the liberal status quo - a point that Wenman picks up, as we will see in the last section, as does Vázquez-Arroyo in his contribution to Robert Nichols' and Jakeet Singh's edited collection.

In particular, Vázquez-Arroyo argues in Freedom and Democracy in an Imperial Context that the absence of a 'sustained analysis of capitalism' (50) in Tully's work specifically, leads him to bracket out the material context and, thus, the way that 
contemporary structures of power limit forms of agonistic resistance, circumscribing their productive effects. Two main features of contemporary capitalist structures are especially irreconcilable with the type of renewal proposed by Tully (and other agonistic theorists I add here) according to Vázquez-Arroyo. The first is that they are obdurate. Continuously reproduced in practices, capitalist relations 'structure different fields of power', 'take the aura of necessity' and are 'tacitly allowed to set the limits of how [agonistic] freedom can be conceptualised' (61). Second, Vázquez-Arroyo highlights the structural unevenness of politics, the ways that the rules of the game are always 'entrenched to the disadvantage of the have-nots, even if the latter can creatively resist them' (61); and this he suggests requires not just confronting capitalist power but also democracy itself which supports it (66).

To be sure, Vázquez-Arroyo is right to suggest that Tully (and I would add Honig and Mouffe) do not theorise differences and contestationsdifferences through the prism of economic and capitalist relations. However, Vázquez-Arroyo is wrong to dismiss the effects that agonistic contests have on the system. A contrast with those radical democrats who suggest the momentary reactivation and subsequent retreat of democracy in institutional structures helps to show that something does change, after all, as a result of agonistic struggles. The idea of reactivation, prominent in different ways in the work of Sheldon Wolin (1996) and Jacques Rancière (1999), assumes that there is a clear separation between institutional politics (conceived of as hierarchical and,-administrative, continuous and obdurate) and popular struggles (conceived of as anarchic, egalitarian and momentary). This separation entails that when popular struggles erupt, seeking to transgress the norms, forms and practices from which they are excluded, democracy becomes reactivated. This reactivation, that gives focus to ordinary people, the have-nots in the case of Rancière (1999), is only exceptional however, in the sense of being only temporarily transgressive. As soon as the democratic struggle has ended, democracy retreats - subsumed into institutions and administration.

Contrasted with the agonistic approach to renewal, this account of change keeps open the possibility for a radical initiative, but bars the prospect of a break from institutions. It recognises the obduracy of institutional structures, but reduces the experience of democracy as a form of political subjectification to a moment. 
By contrast, agonistic theorists insist that while institutional structures remain, the agon is ongoing and atelic and there is at least one serious merit to this insistence. It evades lamentation and grievability (for the democracy gone), a dangerous recourse, as Honig shows in Antigone Interrupted. If politicised, however, and by this Honig means rendered agonistic, seen as an ongoing agon seeking to 'litigate or redress a wrong' (120), then grievability turns to a powerful political resource. Subjects divide, take sides and challenge dominant practices and norms. While these practices and norms will neither radically transform nor simply return, they might open up and this is no small thing (if we think, for example, of discussions about gay marriage).

Nevertheless, the agonistic account of renewal promises a democratic openness that as the discussion has so far intimated, appears to be too little in the face of ebdurate, capitalist and structural forms of domination. The question then becomes: what is radical in agonism? If what issues from an agonistic struggle is only openness, neither a radical initiative nor an exceptional politics that at least confronts the obduracy of dominant structures, then why isn't agonism an edgy version of liberalism? I would suggest that what differentiates agonism from mainstream liberal theory, at least at this level of discussion, is that it accentuates the need for and possibility of an alternative, that things can be otherwise if attention is given to the differences that dominant or hegemenic orders exclude and silence. At the same time, agonistic theory carves out its own account of political change and in situating it within the frame of democracy, without turning a blind eye to its limits, points to an alternative that breaks the impasse of a democracy either dead or gone. Whether this alternative is sufficient will be discussed in the last section. The subsequent sections fill in the details of this alternative by discussing further the particular forms it takes in Agonistics, Global Citizenship and Antigone Interrupted.

\section{Unpacking the Differences: Democratic Institutions, Agonism and Renewal}

The previous section explored the similarities among the agonistic theories of Honig, Tully and Mouffe apropos of the modality of democratic renewal. It laid emphasis on the idea that for agonistic theorists in contrast with other radical democrats, renewal is possible within the frame of liberal and institutional democracy. The aim of this section is somewhat different. It draws out the differences between Tully, Honig and 
Mouffe and shows that they diverge not only on their diagnosis of what constitutes the key challenge for democracy today, but also on the locus and steps to eliciting renewal. Mouffe's Agonistics will be discussed first.

\section{Hegemonising Institutions (Mouffe)}

Mouffe's main concern in Agonistics is with neoliberal hegemony. Her aim is to identify a strategy for constructing instituting a an alternative, counter-hegemonic order_- To institute a counter hegemonic order, that addresses the institutional limits of contemporary democracies in such a way that neoliberalism looses its hegemonic status. Mouffe call this radical politics needs to develop a-strategy _ofengagement with state-institutions'. Radical politics, she says, . It cannot envisage a withdrawal from institutions the way that theorists such as Hardt and Negri suggest because institutions are one key terrain of hegemonic struggle. They can also become a vehicle for struggle (76), giving expression to the division and many demands of the demos.

A particular view of the nature of neoliberal hegemony underpins the emphasis that Mouffe places on institutions as the locus of renewal - rooted in Hegemony and Socialist Strategy co-authored with Ernesto Laclau. It suggests that neoliberal discourse succeeded in becoming hegemonic by making a series of moves (decisions, exclusions, appropriations and neutralisations) in a variety of terrains. If an array of moves is, thus, behind the success of neoliberal hegemony - neither a single logic nor a veil of ideology; then the first step for a radical politics that seeks to challenge this hegemony is to cast light on and expose its moves in the multiplicity of the fields they have taken place, including state institutions. Mouffe labels this first step 'disarticulation'. It captures the moment of critique thatand contestation that is, according to her, necessary to reveals the unnaturalness of the current hegemonic order. However, this moment is not sufficient on its own. To foment another, more democratic, order the movement of 're-articulation' is just as important, according to Mouffe. Re-articulation constitutes the second tenet of the 'strategy of engagement with'. It captures the moment of constructing a counter-hegemonic order_a construction that Mouffe ties with the revival of representative functions. and Mouffe goes as far as to explicate specific paths to its construction: identifying a narrower 
adversary than neoliberalism; 'combining parliamentary with extra parliamentary struggle'; creating 'a synergy between a plurality of actors' and 'launching a war of position in a multiplicity of sites' (75).

Just as notably, Mouffe's emphasis on the movement of re articulation leads her to develop a strong defence of representative democracy. On the back of the assumption that the problem today has to do with the way that representative institutions function, not with representation per se as Hardt and Negri suggest, Mouffe proposes the deepening of representative functions and a hegemonisation of party institutions. Representative functions are deepened when liberty and equality are better enforced by securing, for example, more inclusive and alternative forms of party representation so that citizens feel they have choice and political voice. At the same time, 'the emergence of a genuine left' party that challenges neoliberalism from within the system, can further strengthen representative democracy (120). This is what, in the end, Mouffe means by constructing a counter-hegemony hegemenisation-in this context: renewing our commitment to 're-establishing the priority of democratic valuesthe values of liberty and equality by securing through institutionalised adversarialism (that is, agonism) that they are not hijacked by the one interpretation that neoliberalism offers without relinquishing liberal representative institutions' (124). -While this kind of counter-hegemonic construction stops short of a radical break, the type of renewal it calls for in terms of left politics, charged with the task of recovering the appeal of democratic values within an institutional setting, is for Mouffe no less radical than the transformative politics of theorists such as Hardt and Negri. On Mouffe's account, radicalisation comes down to a deepening of institutional functions - struggles within and against democratic institutions - and to this end, the spread of self organising practices is not sufficient. Therefore, it comes as little surprise that the extension of democracy and the spread of self organising practices, which is interestingly what Tully suggests, is not enough for Mouffe. Democratic struggles from her perspective need to be played out within and against dominant institutions if they are going to have an effect.James Tully thinks otherwise.

Expanding Democracy, or Never Mind the Institutions (Tully) 
In Global Citizenship, Tully affirms the importance of institutional politics, but he does not go as far as Mouffe -portraying institutions as the locus of change - in fact, the very opposite. Seeking to explore and open up the "new field of possibilities of another, more democratic world' (6), Tully redescribes and, in the process, expands the very meaning of democracy.

Redescription is a central dimension of Tully's approach to public philosophy. Along with critique, the calling into question of what appears to be normal, necessary or given, redescription elicits a modification of the rules of the democratic game and, in so doing, opens up possibilities that these rules have either been-repressed or foreclosed_by 'inherited languages of description and reflecti_on' (Tully, 2008, p.19). In this respect, redescription can be likened to Mouffe's re-articulation. Both processes supplement critical activity; they rework the limits of prevailing practice and, crucially, they create possibilities for another_, different, kind of practice. However, there is a pronounced difference between the two processes. While rearticulation initiates-creates something anew - therefore, it is no coincidence that Mouffe often reverts to the notion of 'construction'; redescription inscribes something differently - therefore, Tully often reverts to the term 'modification'. Although modification might be viewed as a limited objective, its intent and, certainly, effect is no less radical than Mouffe's movement of re-articulation. It profoundly unsettles and augments what goes by such taken-for-granted names as 'democracy' and 'citizenship'.

In Global Citizenship Tully seeks to decentre the singularity of modern citizenship (rights and institutionally based) by redescribing struggles that do not immediately meet its criteria as practices of diverse citizenship. At the centre of this redescription lies the idea, familiar to the readers of Tully's earlier work, that diverse citizenship - a negotiated, contextualised and ongoing practice - 'manifests the freedom of and in participation, and with fellow citizens' (39). This idea enframes three propositions. The first is that subjects citizenise, that is, they express their freedom of participation when they agonistically contest and resist relations of governance - understood here in the expansive sense of control and direction. Second, such citizens engage in what Tully designates as Spielraum (44-45), an open ended free play with governors, where they renegotiate the terms of the governing relation, thereby experiencing their 
freedom in participation. Third, and as a result of the above, citizenship so modified transgresses institutional settings and arises in - or, in fact, extends to - relationships. Tully distinguishes between two types of relationship, citizen-governance relationships that he views as reciprocal and mutually enabling and citizen-citizen relations of civic friendship and mutual trust (for example, social movements, urban communes and cooperatives). Citizen-citizen relations and, particularly, cooperatives are especially promising for eliciting change, according to Tully. They 'enact alternative worlds' that embody the very type of change that they want to see in the current system (63). Therefore, such alternative communities already travel down the road to radical and lasting change and effectively map out its contours.

Indeed, acting otherwise in a non-violent way is Tully's alternative to Mouffe's vocabulary of confrontation and 'war of position'. On the back of the assumption that the problem today has to do with the limits of institutional participation - that is, with the incapacity of citizens to elicit global reform for such pressing issues as climate change, inequalities and global poverty - Tully proposes diverse citizenship as another way of being empowered, having a say and experiencing self-government. This experience of self-government, of acting otherwise in the here and now, is from Tully's perspective as important to a better democracy as is Mouffe's emphasis on partisanship.

Nevertheless, acting otherwise draws on different resources to partisanship. As Aletta Norval explains, in her contribution to Nichols and Singh's edited collection, acting otherwise starts from 'a sense of dislocation' from 'our' familiar ways of making sense of the world' (186) and moves on to a negotiation between different ways of conceiving the world that opens up and pluralises the possibilities of alternative identifications. In this negotiation, both imagination and an embedded sense of knowledge play a key role, according to Norval. While imagination, 'conceived as an interpretative act' (189), helps to identify and make connections between possibilities - and is, thus, key to the development of alternatives; an embedded sense of knowledge enables the connection between different senses of selfhood or what Norval refers to as 'being able to find one's way with another' (196). By contrast, partisanship that Mouffe makes the case for draws on the existing 'grammar' of politics. No less than partisanship, however, acting otherwise remains confined to the 
frame of liberal democracy - the context it is situated in - and maps out alternatives that aim to better it. This mapping is exactly what is missing from Bonnie Honig's account of renewal as the next section shows.

\section{Pluralising the Agon (Honig)}

The discussion has so far suggested that both Tully and Mouffe tie renewal with a two-step process that first uncovers and then re-articulates (Mouffe) or redescribes (Tully) repressed alternatives. Bonnie Honig's account of renewal displays nuanced differences from Tully's and Mouffe's. While it is also concerned with uncovering repressed alternatives, this uncovering only stems from and consists in the pluralisation of agonistic practices of dissent and disruption. This subtle difference reveals that the type of renewal that issues from Honig's account is more limited in its intent than Tully's 'modification' and Mouffe's 'counter-hegemonic construction', since it remains content with the creativity generated by everyday resistances and their potential to redirect and expand on institutional democracy. Antigone Interrupted attests to and exemplifies this endeavour to align democratic transformation-renewal with pluralisation and, inevitably, ordinary work of repair.

Antigone Interrupted is an interesting book because by developing a new reading of Sophocles' play, Honig directly challenges dominant assumptions of radical democracy. Antigone, she notes, is 'a text we take to be radical, a text often taken as the founding text of radicalism' (194), for it is seen to embody the politics of dissidence, heroism, lamentation and counter-sovereignty that much Left democratic thinking is attached to. To counter these assumptions and reveal another, agonistic Antigone, Honig places the play within the context of fifth century burial practices in Athens and she suggests that its heroine defends aristocratic practices of burial that democratic Athens (represented by Creon) had outlawed. Therefore, Antigone, on this reading, does not simply resist Creon's sovereign power, but also, crucially, she seeks to subvert sovereign power while she defends another order. Antigone is, in other words, something more than a dissident and a lamenter, according to Honig. She is a 'partisan political actor' (95). Although she laments, her lamentation is itself a contested practice, an agon between different orders. At the same time, Honig's reading reveals that Antigone, far from being the lone, heroic, actor that much radical 
democratic thought celebrates, is conspiratorial and sororal. She plots and seeks to mobilise publics. Antigone is thus an ordinary actor through Honig's lens, and this Antigone decisively 'breaks many theorists fascination with rupture over the everyday; powerlessness over sovereignty and heroic martyrdom over the seemingly dull work of maintenance, repair and planning for possible futures' (2).

The implications of this reading are noteworthy for democratic theory. Certainly, it challenges the idea that renewat-change will issue from some extraordinary politics, not only because such politics is, as I have already mentioned, impossible from an agonistic perspective, but also because radical actors (even as famous as Antigone) never transgress the divisions constitutive of politics - they ascribe to a cause, defend and promote this cause through ordinary means and everyday practices within the frame of their existing world. Political actors then, much like Antigone, 'work on the interval', as Honig puts it following Rancière (146). They stage contests between orders, identities and practices and it is the pluralisation of these contests that, in the end, renews the institutionally settled democracy. The question then arises of whether this type of renewal is enough. The next section delves into Wenman's work and discusses the limits of the agonistic account of renewal.

\section{The Limits of the Agonistic Account of Renewal}

The previous section highlighted some differences in the way that Honig, Tully and Mouffe approach democratic renewal. These differences issue partly from the nuanced strategies they propose: re-articulation (Mouffe), modification (Tully) and pluralisation (Honig). The differences also issue from their diagnoses of contemporary problems. While for Mouffe the problem is, as we have seen, neoliberal hegemony, for Tully it is the inability of ordinary citizens to elicit change through the institutional means available to them - it is not neoliberalism tout court. By contrast, Honig's attack on accounts of transformative politics on the one hand and theories of grievability on the other, draws attention to the lack of appreciation for the ordinary work of institutional repair within contemporary democratic theory. In view of these different emphases, Honig, Tully and Mouffe identify three separate, albeit complementary, paths to renewal: institutional regeneration (Mouffe), creative disruption (Honig) and enactment of an alternative in the here and now (Tully). Are 
these sufficient, given the limits of contemporary democratic institutions to register, let alone address, rampant inequalities and worsening living conditions in their midst? This is the question that the present section addresses and a good starting point here is Mark Wenman's thought provoking book Agonistic Democracy: Constituent Power in the Era of Globalisation.

In Agonistic Democracy Wenman is dissatisfied with the agonistic account of renewal. What Wenman finds particularly dissatisfying in agonism is not the theory per se - after all, he stages a debate within, not against, agonism - but the fact that it forecloses the possibility of 'new beginnings that might discontinue the basic social and political forms of modern liberal democratic constitutionalism' (264). Wenman suggests that agonistic theory must take this possibility into account - which he ties with the Arendtian modality of revolution - if it is to avoid complicity with the status quo. Besides, current conditions of domination call for a 'more militant stance' towards institutional democracy and to develop this stance agonism needs to engage in a more forthcoming critique of liberal democracy.

Seeking, then, to move agonism to the direction of such critique, Wenman reworks the idea of revolution and suggests that understood as the human capacity for creation, revolution can be made compatible with agonism. There is nothing in the agonistic account of pluralism, tragedy and conflict - the defining features of agonistic theory according to Wenman - that contradicts a focus on the ways in which new principles might be created out of the agon. At the same time, Wenman finds in the agonistic emphasis on transnational social movements a mainstay that, if taken further, can incorporate the modality of revolution.

Transnational social movements, he argues, often exhibit the capacity for creation that the idea of revolution denotes. Agonistic theorists praise such movements and, crucially, link them 'to the possibility of new forms of cosmopolitanism (Mouffe aside)' (269). Wenman further strengthens this link and he proposes a militant cosmopolitanism 'concerned with the capacity of democratic actors to generate new social and political forms subsequently recognised to be of wider significance, so that they are picked up and carried forward by different actors and spectators in different locales and become the foundation of an expanding open-ended form of universality' 
(270). On this account, agonistic contests spring from militant conviction and couple with the exercise of agonistic judgement. While militant conviction serves as source of new values, the judgement of varied spectators helps to identify and universalise the new initiatives brought into existence. Universality, as Wenman understands it here, is not the same asdenotes impartiality. Rather, it is an agonism of reciprocal judgements - an ongoing 'dispute about the status of particular acts' (280) - an agonism of reciprocal judgements - that, mediated by post-sovereign leadership, holds open the door to initiating and augmenting new norms and principles. Does Wenman's militant cosmopolitanism transgress the limits of agonistic augmentation?

No doubt, Wenman's book invites the reader to reflect on the Janus face of the agon: its genuinely renewing effects and reiteration of liberal democracy. In so doing, he sharply shows that what appears, in the first instance, to be a pragmatic way of deepening contemporary politics turns out, on closer inspection, to be limiting _ in view of the challenges confronting contemporary liberal democracies. Liberat democracy is seriously under strain today because of rampant inequalities and the consolidation of neoliberal policies. In this context, the idea that an ongoing agon only expands what there is transpires as insufficient. The question then becomes whether a militant cosmopolitanism overcomes the limits of agonistic theory. Wenman does a good job in showing, first, that augmentation and revolution are not opposites and, second, that the modality of revolution, understood as the human capacity for creation, can credibly constitute a tenet of agonistic theory. However, he so convincingly recasts agonism that it can be questioned whether, in the end, his account of militant cosmopolitanism transgresses the limits of agonism. If the exercise of judgement, that new initiatives hinge on, remains open and ongoing, then this account of judgement is in a sense already latent in agonistic theory - in that agonistic contests have unavoidably been judged as worthy enough to be taken up. While democratic augmentation is not anymore the only option for agonistic contests, it is unclear how (and what kind) of 2 new ideas will emerge to challenge and unsettle the dominant order.

Following Boltanski and Chiapello's (2007) analysis of the 'third spirit of capitalism', I would suggest that the limit today might have less to do with the emergence-absence of new ideas and initiatives and more with the absorption and co-optation of the ideas 
and initiatives that there are by a networked capitalism. If this is the case, then perhaps the agonistic way of addressing the limits of the current order, with its emphasis on openness, underestimates the hurdles involved in securing a more democratic order. To overcome these hurdles, it is necessary, as Boltanski and $\underline{\text { Chiapello remind us, to revive the social critique - based on claims to social and }}$ economic equality - alongside the critique of the closures, normalisations and hegemonies of the current order. Despite their contradictions, both critiques need to be kept alive, if the excesses that each one risks on its own are to be avoided (2007, 536) and a more equal and democratic world is to emerge.

an alternative, such as egalitarianism, needs not just to be initiated and brought to the fore, but alse, crucially, proclaimed and endorsed. Of course, to endorse egalitarianism is, as we have seen, to close off the agon according to agonistic theorists. Wenman included to promote a good other than openness. But still, if openness, comes down to a good (and this is no-mall thing), then perhaps egalitarianism and a more democratic, not just liberal, world is the price to be paid.

\section{Bibliography:}

Badiou, A. (2012) The Rebirth of History: Times of Riots and Uprisings. London and New York: Verso.

Boltanski, L. and Chiapello, E. (2007) The New Spirit of Capitalism. London and New York: Verso.

Hardt, M. and Negri, A. (2012) Declaration. New York: Argo Navis Author Services.

Honig, B. (2013) Antigone, Interrupted. Cambridge: Cambridge University Press.

Laclau, E. and Mouffe, C. (2001) Hegemony and Socialist Strategy: Towards a Radical Democratic Politics. London and New York: Verso.

Mouffe, C. (2013) Agonistics. London: Verso. 
Nichols, R. and Singh, J. (eds) (2014) Freedom and Democracy in an Imperial Context - Dialogues with James Tully. Abington and New York: Routledge.

Rancière, J. (1999) Disagreement: Politics and Philosophy, translated by J. Rose. Minneapolis, MN: University of Minnesota Press.

Tønder, L. and Thomassen, L. (2005) 'Introduction: Rethinking Radical Democracy Between Abundance and Lack', in L. Tønder and L. Thomassen (eds), Radical Democracy: Politics Between Abundance and Lack. Manchester: Manchester University Press, 1-13.

Tully, J. (ed.) (2014) On Global Citizenship. James Tully in Dialogue. London and New York: Bloomsbury Academics.

Tully, J. (2008) Public Philosophy in a New Key Vol. I. Democracy and Civic Freedem. Cambridge: Cambridge University Press.

Wenman, M. (2013) Agonistic Democracy: Constituent Power in the Era of Globalisation. Cambridge: Cambridge University Press.

Wingenbach, E. (2011) Institutionalizing Agonistic Democracy: PostFoundationalism and Political Liberalism. Surrey and Burlington: Ashgate.

Wolin, S. (1996) 'Fugitive Democracy', in S. Benhabib (ed.) Democracy and Difference: Contesting the Boundaries of the Political. Princeton, NJ: Princeton University Press, 31-45.

Žižek, S. (2011) Living in the End Times. London and New York: Verso. 